\title{
Cunhataí: ficção e história intermediadas pela memória
}

\section{Cunhataí: fiction and history intermediated by memory}

\author{
Marinalva da Silva Pedro de Almeida', Paulo Bungart Neto²
}

Mestre em Letras, área de concentração: Literatura e Práticas Culturais. Universidade Federal da G Praticas Culturais. Uninde Dourados (UFGD).

E-mail: nalvapedro18@hotmail.com

Professor Doutor. Docente do Programa de Mestrado em Letras da Universidade Federal da Grande Dourados (UFGD). Projeto de pesquisa: "Literatura brasileira contempong aubiografias, historia(s).
RESUMO: Através da análise de Cunhataí: um romance da Guerra do Paraguai (2003), de Maria Filomena Bouissou Lepecki, pretende-se abordar questões relacionadas aos discursos ficcional, memorialístico e histórico, ligadas a um enredo ambientado no espaço geográfico e cultural do que, na época, tratava-se da fronteira entre Brasil e Paraguai na região equivalente ao sul do Mato Grosso, hoje Mato Grosso do Sul. A proposta consiste em salientar as possíveis inter-relações entre ficção, memória e história no romance, que apresenta como pano de fundo a Guerra do Paraguai, sendo possível perceber a mescla dos discursos literário e histórico que, intermediados pela memória, se complementam na narrativa. Com o intuito de salientar a relevância do romance enquanto narrativa contemporânea, cuja contribuição é significativa para a compreensão da memória cultural do povo brasileiro, especialmente para a formação histórica do Mato Grosso do Sul, interpretamos certos aspectos do romance seguindo rastros da história recuperados por intermédio da memória. Assim, é sob o ponto de vista de uma "revisitação" e de uma ficcionalização com base nos relatos sobre a Guerra do Paraguai que Cunhataí surge com uma abordagem inusitada pela própria dessacralização do registro conhecido como "oficial".

Palavras-chaves: Cunhataí; Ficção; História; Memórias.

ABSTRACT: The analysis of Cunhataí: a novel of Paraguayan War (2003), written by Maria Filomena Bouissou Lepecki, is intended to approach issues related to fictional, memorialistic and historical speech connected to a story that took place in a geographic and cultural neighborhood, which formerly was the border between Brazil and Paraguay. This region was equivalent to South of Mato Grosso, nowadays known as Mato Grosso do Sul. The present proposal is to point the possible interrelations among fiction, memory and history in the novel, which presents the background of the Paraguayan War, where it is possible to see the mixture of literary and historical discourse, mediated by memory, complement the narrative. In order to stress the relevance of the novel as a contemporary narrative, whose contribution is significant for understanding the cultural memory of the Brazilian people, especially for the historical formation of Mato Grosso do Sul, it was analyzed certain aspects of the novel following traces of history recovered through memory. Thus, it is from the point of view of a "revisitation" and a fictionalization based on reports of the Paraguayan War that Cunhataí comes up as an unusual approach by the desecration of the record known as "official".

KeYwordS: Cunhataí; Fiction; History; Memories. 


\section{Introdução}

Alguns dizem que se deve escrever sobre o que se conhece, em prol da verossimilhança; outros acreditam que é justamente na tentativa de compreender o desconhecido que nascem as melhores histórias; de minha parte penso que se deve escrever sobre o que nos encanta, indigna, amedronta, fascina, e que sobretudo nos prende e nos habita, às raias da obsessão. De uma energia assim é que nasceu o Cunhataí (...) ${ }^{1}$. (LEPECKI apud FNLIJ, 2004, p. 3)

$\mathrm{M}$ aria Filomena Bouissou Lepecki ficcionaliza, em Cunhataí: um romance da Guerra do Paraguai (2003), um importante episódio ligado ao maior conflito bélico ocorrido na região da fronteira entre o Brasil e o Paraguai. Por sua relevância, o romance obteve três prêmios literários: além da conquista do prêmio Fundação Conrad Wessel de Literatura/2002, no Museu da Casa Brasileira em São Paulo, as apreciações e julgamentos da obra também levaram sua autora a conquistar o prêmio “Escritora Revelação 2003" pela Fundação Nacional do Livro Infantil e Juvenil, ao lado de outros grandes escritores como Ana Maria Machado, Marina Colassanti e Manoel de Barros; e o Prêmio FNLIJ “O Melhor para o Jovem 2003". Conquistas que contribuíram para situar o romance dentre algumas das principais obras literárias contemporâneas.

O reconhecimento, por parte da crítica literária, proporcionou que o romance e sua autora alcançassem um espaço significativo na área da literatura. Assim, a escritora brasileira conseguiu fixar seu nome e obra no mundo da literatura nacional, tornando-se objeto de investigação, principalmente por referir-se a um marco histórico que mexe em feridas profundas para grande parte da população da América do Sul: a Guerra da

${ }^{1}$ Disponível em: <http://www.fnlij.org.br/site/jornal-noticias/item/706-outubro-de-2004.html>. FNLIJ -
Fundação Nacional do Livro Infantil e Juvenil, Notícias, v. 26, n. 10, p. 3, out. 2004. Acesso em: 18 jul. 2016.
Tríplice Aliança, mais conhecida no Brasil como “Guerra do Paraguai” (18641870). E, ainda, por abranger teorias que celebram o espaço da alteridade, do duplo e da mescla entre os vários ramos do saber.

Lepecki define Cunhataí como um livro de "raízes", uma ficção histórica que apresenta, como pano de fundo, o importante episódio da Guerra do Paraguai. Sabe-se que o discurso ficcional é tomado como sinônimo de invenção, de simulação, no qual se agrupam os discursos de representação e, mais especificamente, o literário. O histórico é considerado sinônimo de narrativa de fatos relacionados a uma suposta "realidade" ou "verdade"; e o discurso memorialístico, por sua vez, abarca questões próprias da identidade, individual ou coletiva, isto é, relacionadas à memória enquanto reelaboração de informações vinculadas a certa consciência do passado.

O assunto "Guerra do Paraguai" está presente em estudos de historiadores, jornalistas e pesquisadores das mais diversas áreas do conhecimento. Junto àqueles que se interessam pela temática dessa Guerra estão os escritores que dela se utilizam para produzirem ficção. Literatos, em diálogo com historiadores, estendem sua "versão" da guerra de maneira tal que, ao mesclar personagens históricas e fictícias, promovem a dessacralização da história "oficial”, questionando a autenticidade dos fatos registrados.

Atentando para a posição geográfica do estado de Mato Grosso do Sul, outrora apenas Mato Grosso, palco do confronto armado justamente pela sua posição fronteiriça, o olhar sobre a temática dessa guerra está estritamente vinculado à história do povo e da terra sul-mato-grossenses. Região fronteiriça com outros países como Paraguai e Bolívia, o estado tem se constituído como uma espécie de "ponte", passagem ou travessia, algo que permite o trânsito, a mobilidade do múltiplo e a variedade de sujeitos dos mais diversos lugares e nações que, consequentemente, se inserem no constructo identitário do povo. 
Hoje, um século e meio após os acontecimentos da Guerra, a riqueza histórica da terra sul-mato-grossense perpassa pela temática da Guerra do Paraguai e encontra-se, ainda, entre os fecundos temas pesquisados e explorados, sendo recorrente em tantos trabalhos conceituados e, igualmente abordada por historiadores (embora sob outro ângulo), tem sido mote gerador de obras literárias.

A mesma guerra, tão "real" em suas consequências trágicas e desumanas, que influenciou produções literárias interessantes, exemplos representativos do universo literário que circulam pelas fronteiras das instâncias discursivas, inspirou também a autora de Cunhataí, cuja obra parece estabelecer uma relação harmônica e vantajosa entre ficção, história e memória, representada no ato de contar e/ou reconfigurar, no presente, um passado recriado e reapresentado aos leitores do século XXI.

\section{Os relatos de Taunay: o discurso referencial em Cunhataí}

Observa-se, a partir do olhar de historiadores como Francisco Doratioto (2002), Acyr Vaz Guimarães (1999) e Júlio José Chiavenato (1990), dentre outros, que o acontecimento histórico da Guerra, sucedido no contexto do Brasil Imperial, sob o governo do Imperador D. Pedro II, é considerado o maior conflito bélico ocorrido na América durante o século XIX. Uma guerra ocorrida em território sul-americano, na qual, o Paraguai lutou contra a Tríplice Aliança, formada por Brasil, Argentina e Uruguai, e que culminou na morte de milhares de pessoas, dentre civis e militares.

Em meio a tantas possibilidades, a principal causa para o início da Guerra, apontada por muitos pesquisadores, era a ambição do presidente do Paraguai, Francisco Solano López, originada já nos governos anteriores do país, aspirando a uma saída para o Oceano Atlântico:
No Brasil, só se referiam a ele como "o ditador". Sanguinário era pouco. Todos o consideravam um monstro. Mas o monstro era seu amigo. E nada do que dissessem contra ele mudaria isso. Será que ninguém sabia, neste Brasil tão vasto, o grande mediador que Solano era em conflitos entre províncias? [...] Por acaso desconheciam que o Paraguai e Solano eram um só? Que o povo o venerava referindo-se a ele como El Supremo, a antiga alcunha de Francia? (LEPECKI, 2003, p. 131).

O governo paraguaio pretendia possuir terras na região da Bacia do Prata, que compreende três dos grandes e principais rios mais extensos do mundo: o rio Paraná, o Paraguaie o Uruguai, cujo limite localiza-se em frente a Montevidéu. Acredita-se que foi com essa intenção que tropas de Francisco Solano López apreenderam, em novembro de 1864, o navio brasileiro Marquês de Olinda, que trafegava pelo rio Paraguai, dando início, com tal ação, ao conflito gerador da guerra.

Solano pensara em tudo. Em dezembro de 1864, ao sequestrar o navio brasileiro Marquês de Olinda que transportava o futuro governador da província de Mato Grosso e várias autoridades que o acompanhavam para a posse, tinha dado início à guerra. Os prisioneiros já começavam a sucumbir nas prisões insalubres do Paraguai. O imperador mal tomara conhecimento do fato e os navios comandados pelo general Barrios subiam o rio Paraguai para invadir Corumbá. A resistência heróica [sic] no forte Coimbra fora surpreendente, embora vã. Logo os paraguaios tinham dominado a cidade que ainda se esvaziava às pressas. Os civis e militares que subiram o rio levaram a notícia a Cuiabá. Como eles deviam estar apavorados! Os que se haviam embrenhado pelos pantanais deviam estar ainda vagando por lá. Guerra é guerra! (LEPECKI, 2003, p. 186-187).

Com o mesmo intento, em dezembro de 1864, ao invadir o Mato Grosso, soldados paraguaios iniciavam as operações bélicas em território brasileiro. Foi a guerra que perdurou por maior tempo no continente americano, com “[...] duração total de quase seis anos, estendendo-se de 11 de novembro de 1864 (tomada do vapor Marquês de Olinda pelos paraguaios) a 1o de março de 1870 (morte de López em Cerro Corá)" (SALLES, 1990, p. 7). 
Ricardo Sales (1990), ao falar das dimensões dessa guerra, dos recursos e forças nela empregadas, das perdas humanas e materiais, destaca o conflito como um dos fatos "esquecidos" de nossa história, que ora é abordado pelo viés da historiografia oficial, ora é tema dos que revisam nossa formação histórica. Salienta que, enquanto uns se dedicam a derrubar os mitos oficiais da guerra, muitos trazem à luz outros mitos sobre o conflito, e é dentro desse espaço, repleto de frestas, que se encontra Cunhataí com suas muitas referências alusivas à guerra:

Desde a vitória da esquadra imperial na batalha do Riachuelo em 11 de junho de 1865, o Paraguai não possuía mais saída para o mar. Seu único canal de comunicação com o mundo era feito através da Bolívia. Com a destruição completa de sua marinha, os paraguaios concentravam seus ataques por terra. Já tinham assegurado posições no Mato Grosso, forte de Coimbra, em Corumbá, Nioac, Dourados, Miranda, Bela Vista e Coxim. Para penetrar no sul do Brasil, tinham invadido Corrientes, na Argentina. As cidades brasileiras de Itaqui e São Borja no Rio Grande do Sul estavam em mãos paraguaias. A tríplice Aliança entre Argentina, Brasil e Uruguai havia sido firmada desde maio de 1865 (LEPECKI, 2003, p. 242).

Dentre algumas das principais obras que formam a fortuna crítica sobre a Guerra do Paraguai estão os relatos de Visconde de Taunay, que fez parte da tropa brasileira enviada para a região mato-grossense do conflito e testemunhou sua experiência em volumes como A retirada da Laguna (2003) e Memórias (2004), sobretudo o primeiro, que registra episódios ocorridos entre 8 de maio e 11 de junho de 1867, e é considerado um dos primeiros relatos sobre o drama vivido pelos soldados brasileiros durante a retirada das tropas da região em que ocorreu o embate. Lepecki menciona o episódio:

[...] A guerra, então em pleno andamento mobilizando tropas do Brasil inteiro, iria formar naturalmente um poder paralelo. Um exército forte, com generais respeitados e apoio das armas e dos súditos, poderia oporse ao imperador. Em meio a elucubrações e devaneios, imaginavam uma chance de república. Todavia, mesmo com aspirações nada monarquistas, naquela noite [...] concordaram que, antes de qualquer fato novo, se fazia premente lutar contra o invasor. Era preciso vencer o Paraguai! Afinal eram acima de tudo brasileiros e patriotas! (LEPECKI, 2003, p. 23)

A ficção de Cunhataí dialoga com os escritos de Visconde de Taunay, apresentando-o como uma das personagens históricas que, aos olhos do leitor, mantém estreita convivência com as fictícias no romance, como se vê no diálogo que segue:

[...] 0 material é este - e passou a Micaela uma pilha de desenhos e pinturas. Ela os examinou rapidamente (...) - Mas são ótimos! Não sabia que além de conhecedor de botânica é também um artista! (...) - São apenas uns riscos sobre papel. Artistas de verdade, só meu pai e meu avô. (...) - Bem se vê que teve bons professores. E que variedade! A lápis, a pena, algumas aquarelas... (...) - Feito nas horas de lazer deste janeiro arrastado que nós acabamos de vencer. Costumo traçar as linhas gerais pelo caminho, dando destaque somente a um ou outro pormenor, para finalizar com cuidado quando há mais tempo (LEPECKI, 2003, p. 179).

Em suas memórias, Taunay (2004, p. 179) declara: “Com a educação artística que recebera de meu pai, acostumado desde pequeno a vê-lo extasiar-se diante dos esplendores da natureza brasileira (...) ia olhando para os encantos dos grandes quadros naturais e lhes dando o devido apreço". Tal apreço é pontuado por Lepecki, que descreve, dentre as atividades desenvolvidas pelo memorialista, a dedicação em registrar, através de seus desenhos, os lugares por onde passava: paisagens, fauna e flora da região nas quais a guerra ia deixando seu rastro, no interior do Mato Grosso.

O tenente falava dos trabalhos da engenharia com garbo e orgulho, ciente da importância deles ao longo de todo o percurso que faziam. Micaela percebeu o brilho no olhar do oficial ao referir-se às explorações do passado e podia jurar que ele adorava ter feito parte delas (LEPECKI, 2003, p. 150). 
Esse é apenas um dos aspectos recuperados no romance Cunhataí em que a memória do acontecimento narrado dessacraliza o registro oficial da guerra. São muitas as reflexões sobre os acontecimentos envolvendo a Guerra da Tríplice Aliança, o que torna múltipla e plural a sua interpretação. Cunhataí trata do tema de forma diferenciada, permitindo que um fato considerado histórico seja revisitado, não apenas para reproduzir o passado, mas para reinventá-lo, e, com isso, oferecer ao leitor algo novo a respeito dessa guerra que causou a morte de quase toda a população do Paraguai, assim como a destruição do Estado e a perda de territórios: "E a guerra ali era o que sempre foi e sempre será: a maior estupidez humana" (LEPECKI, 2003, p. 390). A população paraguaia ficou reduzida muito mais devido a doenças, fome e exaustão física do que aos combates propriamente ditos: "O Paraguai, arrasado pela guerra, perdeu a maior parte de seus homens, enquanto a Tríplice Aliança obteve uma vitória difícil e a um custo altíssimo. Ninguém, mas ninguém mesmo, imaginava que os paraguaios fossem resistir tanto" (LEPECKI, 2003, p, 402).

A retirada da Laguna e as Memórias de Taunay podem ser utilizadas para destacar alguns aspectos do saber histórico presente em Cunhataí. Mesmo porque, além de os livros de Taunay serem utilizados como textos "oficiais", como fontes dos relatos da expedição, a primeira obra é também citada, explicitamente, no romance Cunhataí.

A retirada da Laguna e alguns personagens históricos ali presentes, dentre os quais o próprio Taunay, são ressignificados por Lepecki - estratégia que possibilita agregar o que é considerado "história oficial" da Guerra à ficção e as personagens históricas às ficcionais, permitindo "fundir" o que é tido como "real" àquilo que é imaginação. Dessa forma, Lepecki cria um espaço narrativo totalmente distinto, constituído pelo viés da memória que recupera a história para dar origem, a partir disso, à ficção.
- Não! Também é estudiosa de botânica? Que maravilha! Pois saiba que encontrou um par neste tenente! (...) Micaela procurou o compêndio. Enquanto desdobrava o tecido grosso que o protegia, ia explicando a pesquisa da madrinha. 0 engenheiro, boquiaberto, folheava o livro devagar. As exclamações saíam inflamadas: _- Magnifico! Que iniciativa prolífica! (...) Como ninguém não pensou nisto antes? - E continuou Este país, madame, este país... Não consigo entender este país. Despreza a maior riqueza que pode almejar! A saúde! Ignora o poder das folhas do próprio quintal! (...) - 0 senhor é tão refinado, ligado às belas-artes por tantas gerações, frequenta a casa do imperador, e, no entanto, fala como a madrinha. Oxalá pudessem ter se conhecido em Campinas. - E a senhora ainda me diz que a mentora deste trabalho é uma simples parteira do interior? Inacreditável! Uma semi-ignorante? (...) - Ah, monsieur Taunay, a madrinha uma semi-ignorante? Não creio. Diria, no máximo, uma rústica. Uma sábia e experiente rústica! (LEPECKI, 2003, p. 151).

Ao entrecruzar os gêneros e romper limites, Lepecki acaba por recuperar o debate contemporâneo sobre as fronteiras entre a literatura e a história, ao mesmo tempo em que instiga o leitor a identificar a tessitura traçada pelas narrativas e percorrer as linhas que podem separar, mas também unir as diferentes categorias dos discursos.

\section{Em Cunhataí: ficção e história intermediadas pela memória}

Através da leitura de Cunhataí, é possível ficar a par dos fatos que estavam acontecendo na guerra, sobre os avanços paraguaios em terras brasileiras e sobre os questionamentos feitos em torno dos motivos da guerra, seguindo, principalmente, a esteira dos relatos deixados por Taunay:

Todas as perguntas ficariam sem respostas. 0 fato era que todos ambicionavam aquela saída para o mar. Depois de declarada uma guerra, as causas perdiam importância. Entravam em cena as estratégias, as intrigas, alianças, batalhas, derrotas e vitórias. No atropelo dos fatos e dos dramas individuais, ninguém se preocuparia mais como tudo tinha começado e porque (LEPECKI, 2003, p. 190). 
A obra traz estampada em seu título rastros da ficção e da história Cunhataí: um romance da Guerra do Paraguai (2003). O nome Cunhataí vem de cunhã, palavra guarani cujo significado é dado pela própria Maria Filomena Lepecki, quando entrevistada pelo jornalista Alexandros Papadopoulos Evremidis, como: “[...] moça nova, em pleno florescimento, bonita, pronta e aberta para o amor" ${ }^{2}$. Tal significado também é reafirmado, na narrativa do romance, pela personagem histórica Guia Lopes, que, quando indagada por Micaela se era de seu conhecimento a língua dos índios e o próprio significado de Cunhataí, respondeu tratar-se de uma "[...] moça nova, moça bonita. Que está pronta para o amor" (LEPECKI, 2003, p. 344). O romance apresenta indícios de que a escolha do termo Cunhataí tenha sido feita justamente para representar Micaela, a personagem principal do segundo plano da narrativa. Essa, ao longo da história e das muitas dificuldades vivenciadas por todos os que participavam da marcha rumo à guerra, encontrará o amadurecimento e, com esse, terá sua própria identidade forjada.

Faria o sacrifício dos anônimos, dos poucos importantes. Seria a heroína desconhecida de um livro nunca escrito. Morreria. Um bom romance nunca tem um final feliz. (...) Apequenou-se. (...) Mergulhou dentro de si para descobrir quem era verdadeiramente, mas não encontrou ninguém lá (...). Aquela era uma guerra perdida pra ela, mas não estava pronta para morrer

(...) Precisava viver. (...) Queria viver! Com uma intensidade que nunca pudera antes imaginar (...) (LEPECKI, 2003, p. 359-360).

Nos cinquenta e quatro capítulos do romance, que se dividem em três partes: "O Caminho"; "O Território"; e "A guerra”, Cunhataí mostra o contexto de aventuras e desventuras vivenciadas pela protagonista Micaela que, dividida entre a atração que sentia por Ângelo e a atenção do capitão Santa Cruz, acaba experimentando o amor em meio às barbáries provocadas pelos atos da guerra entre brasileiros e paraguaios.

${ }_{2}$ Disponível em: <http://www.rioartecultura.com/mariafilomena.htm>. Acesso em: 18 jul. 2016.
Lepecki insere o contexto do conflito da Guerra da Tríplice Aliança em um duplo movimento, por intermédio da leitura de Cunhataí e da leitura de outro texto, praticamente um palimpsesto, um fragmento publicado, supostamente, em um veículo de comunicação de massa, a Gazeta Pantaneira, escrito por uma colaboradora especial, chamada Coralina S. C. Fernandes. Tendo o evento realmente existido em tempo e local determinados, surgem várias perguntas na cabeça do leitor: seria tal fragmento "verdadeiro"? A Gazeta Pantaneira realmente existiu? Coralina era ou foi, de fato, jornalista? Questões que o leitor vai procurando responder ao longo da narrativa de Cunhataí. Indagações que deixam marcas da provável verossimilhança entre a narrativa do espaço ficcional do romance e a narrativa de um fato histórico totalmente fundamentado nos vestígios textuais do passado histórico. Pela ótica da personagem narradora (Coralina), eis o trecho representativo da "Batalha de Nhandipá", que dá início à narrativa:

De repente, como que saídos das entranhas da terra, surgiram furiosos paraguaios, avermelhando os campos. (...) A cavalaria paraguaia posicionou-se à frente e nos flancos, empurrando os brasileiros para o centro do descampado - comprimindo-os - como um abraço gigantesco de tamanduá. (...) Atrás deles, as águas tranquilas do Apa serpenteavam na planície, indiferentes ao desespero dos homens. Bandeiras imperiais foram fincadas no chão, batalhões organizados às pressas para o combate, carroças e mulheres levadas para o centro. Sem cavalaria e sem possibilidade de obter reforços, formaram rapidamente um quadrado compacto de gente e armas à espera do ataque. Os quatro canhões La Hitte, direcionados para fora dos vértices do quadrado, eram os maiores trunfos da defesa. (...). Em quinze minutos era uma carnificina. Muitas mulheres esconderam-se embaixo dos carroções. (...) Mais adiante, outros bravos tombavam feridos.

(...) a cavalaria escarlate, dividida em duas colunas, avançava pelas laterais para uma investida por ali. Para enfrentá-los havia uma dúzia de soldados combalidos e as mulheres. Seria um massacre! (...) Invocou a proteção de Deus e de todos os anjos que se haviam esquecido daquele descampado nos confins do país. Era tarde! (...) Anos depois, este episódio ficou conhecido como a batalha do "Nhandepá" - "Anhan de Apá" -, porque foi o diabo no Apa (LEPECKI, 2003, p. 11-12). 
Assim, a abertura do romance de Lepecki dá a entender que tem por finalidade informar ao leitor o dado que, historicamente, vem a ser o mote desencadeador da construção de toda a narrativa do romance Cunhataí. A obra, que realça um espaço representativo da cultura da região fronteiriça entre Brasil e Paraguai, parte de textos e documentos que, por si sós, já possuem multiplicidade de significados, para, então, abordar a temática da Guerra do Paraguai. Para fazê-lo, a autora, a nosso ver, aproveita-se também do espaço de desenraizamento e desloca-se do ethos nacional (Brasil) a fim de alcançar o espaço transnacional (Paraguai).

Quanto ao enredo, convém destacar o papel conflituoso de Micaela, que se apaixona por um espião paraguaio infiltrado em meio às tropas brasileiras, cujo "[...] objetivo consistia em ouvir sem ser percebido, olhar sem ser visto, interceptar mensagens e observar manobras mantendo sempre um ar casual, desinteressado [...]" (LEPECKI, 2003, p. 30). Por causa desse amor, ela resolve abandonar a aristocracia e, em segredo, usando trajes masculinos, se junta às tropas que saíram do Rio de Janeiro para libertar o Mato Grosso, região invadida pelos paraguaios: “- Quê? É uma moça! - Esperou um minuto antes de continuar: - Mas é a fia de dona Glorinha! Menina, que que a sinhazinha tá pensano [sic]? Que loucura é essa? De calça?" (LEPECKI, 2003, p. 78).

Junto com a tropa brasileira, a "sinhazinha" de Campinas percorreu um percurso que, devido às dificuldades, durou dois anos para ser completado, culminando no famoso episódio historicamente conhecido como "A Retirada da Laguna", rememorado por Taunay e reconstituído por Lepecki:

Não podiam compreender ainda a dimensão da sua tragédia. Era muito estarem vivos. Dos quase quatro mil reunidos no Coxim, tinham voltado 1.300 da Laguna e marchavam para Aquidauana pouco mais de setecentos. E mesmo que lhes fossem curadas todas as feridas, lhes nutrissem os corpos e os cobrissem de medalhas, nada poderia abrandar o peso que levavam em seus corações. (...) No dia 11 estavam no Porto Canuto, nas margens do Aquidauana. (...) No dia seguinte o comandante José Tomás
Gonçalves leu a ordem do dia, cujas últimas palavras eram: "Soldados, honra à vossa constância que conservou ao Império os nossos canhões e as nossas bandeiras!" (...) Terminava ali a retirada da Laguna (LEPECKI, 2003, p. 391).

O enredo revela que a personagem principal, ao optar por seguir a tropa, rompe com a tradição e desafia as convenções sociais, partindo em busca de uma aventura. Todavia, ao passar pelas dificuldades e privações, resolve voltar para casa, mas, devido a uma série de fatores, se vê impedida de retornar.

A narradora-personagem, a viúva Rosália, introduz-se no romance como uma leitora de jornal que, numa manhã de domingo, após ter lido um artigo escrito por Coralina S. C. F., dá início a toda a trama do livro, ao colocar o leitor do romance a par de suas indagações sobre a colega de faculdade que conhecera há trinta anos e a respeito do assunto do próprio artigo, que tratava do histórico episódio conhecido como a "batalha do 'Nhandepá' - 'Anhan de Apá”" (LEPECKI, 2003, p. 12), refrega a que os paraguaios nominaram de “combate de Nhandipá” (TAUNAY, 2003, p. 105).

Tal assunto, que lhe era totalmente desconhecido até aquele momento, aguçava sua curiosidade. Decidida, então, a sair do luto e visitar a amiga a fim de obter esclarecimentos, desloca-se de sua moradia - Fazenda Boqueirão - e vai até a Fazenda São Miguel (moradia de Coralina). Ao chegar lá, pede à amiga que lhe conte sobre o assunto que leu no artigo do jornal. A partir desse encontro, através de outra voz, agora de uma narradora-observadora que exerce a função de também escrever e contar a história, é que o leitor começa a conhecer a história da guerra e da vida da protagonista Micaela: "A sinhazinha de Campinas, mesmo daquele jeito, desprovida de adornos, de cabelos curtos e desalinhados, executando gestos masculinos, ainda tinha seus encantos. (...) Era incrível! A pianista do teatro estava virando soldada!" (LEPECKI, 2003, p. 268). 
Em Cunhataí, Coralina é a narradora que, a partir de suas experiências, mas também da experiência alheia, especificamente no tocante às memórias da personagem Micaela registradas em um diário, acaba organizando todo o enredo e transmitindo um saber adquirido pela vivência; e acaba, por fim, não somente aconselhando, mas também convencendo a personagem Rosália a não mais desejar vender a fazenda onde mora, pelo fato de esta fazer parte da própria história narrada e estar impregnada de valor histórico. Coralina é, então, a típica narradora que possui autoridade para narrar, sendo que esse tipo de narrador é definido por Benjamin como aquele que:

(...) não está transmitindo puramente uma informação, ela mergulha na vida do narrador para retirá-la dele, imprimindo a sua marca na narrativa. Os narradores gostam de começar sua história com uma descrição das circunstâncias em que foram informados dos fatos que vão contar, a menos que prefiram atribuir essa história a uma experiência autobiográfica cujos vestígios estão presentes de muitas maneiras nas coisas narradas, seja na qualidade de quem as viveu, seja na qualidade de quem as relata (BENJAMIN, 1985, p. 205).

Coralina, tendo autoridade para narrar, vai entrelaçando sua própria experiência à alheia (da bisavó) e, de posse dessas experiências compartilhadas, conta a história da própria bisavó, Micaela, tornando-a comunicável, intercambiando-a à da amiga Rosália, mulher a quem transmite o seu saber: "Conto a história do jeito que tem de ser contada. É uma história especial. Está mesmo disposta a ouvir? (...). Ela começou a contar” (...) (LEPECKI, 2003, p.14); e no final da narrativa: "O restante da história ficou para o outro dia" (LEPECKI, 2003, p. 169).

Coralina, Rosália, Micaela e outras personagens são exemplos de mulheres que podem ser observadas a partir de uma perspectiva de exclusão, mas que, "instruídas" e informadas da realidade do conflito, inovam justamente por se fazerem vozes presentes na narrativa que recupera a história da Guerra. Leiamos o final da narrativa:
- Você não me disse se gostou da minha história - Coralina perguntou [...] - Não é uma questão de gostar. Mexeu comigo porque aconteceu aqui, nas nossas terras, nos rios que atravessamos sempre. De certa maneira, sentime ligada a ela. Não é a história mais importante do mundo, é apenas uma história entre tantas. Mas mudou a mim, Rosália. Mudou a minha história pessoal. Não vou vender a fazenda: a sua história mudou também a história da Boqueirão, Coralina. Uma história leva a outra, não é mesmo? (...) - Tem razão. E é nesse emaranhado de tantas histórias que se escreve o livro da humanidade. (...) - Ora, Rosália, o que a gente não sabe, a gente inventa! (LEPECKI, 2003, p. 405-406)

Assim, a narrativa, em seus dois planos, composta pelo diálogo entre Coralina e Rosália para transmitir a história de Micaela, é entrelaçada linearmente à história do conflito. A do primeiro plano se interrompe, naturalmente, para dar lugar à narrativa do segundo plano, na qual a trama da vida de Micaela e seu caminhar na guerra vai sendo aos poucos revelado. É na primeira parte do romance que o leitor fica a par do primeiro encontro entre Micaela e o espião paraguaio com quem se casara sem, no entanto, consumar o casamento na noite que deveria ser de "núpcias". Inicia-se, então, a trilha das três partes que compõem o romance, "O Caminho" que a conduzirá, não apenas ao "Território" da guerra, mas, à própria "Guerra": a interna, individual, de seus sentimentos; e externa, isto é, o conflito em si:

Destino é palavra abrangente. É um objetivo, um fim, um termo, um sumiço. Força invisível que determina os sucessos e revezes de uma vida. Com perseverança é possível enfrentá-lo. Sob inspiração divina, ele se transforma. Se o espírito é forte, dele se pode fugir. 0 destino é maleável. Basta que as escolhas sejam outras e os caminhos, diferentes (...). Sina é coisa fixa. É feita de mármore. Estaca enterrada no chão. Da sina não se foge, da sina não se escapa! É sorte selada, predeterminada. Sina é fatalidade (...) E a sinhazinha de Campinas, moça de fino trato, letrada e de boa família, estava presa à sua sina. (...) 0 que fazer? Para onde correr? [...] A única saída não podia ser pior! (...) E era a de que ela, Micaela, sem querer e sem vontade, de forma abrupta e inesperada, sem opção ou escolha, estava indo para a guerra (LEPECKI, 2003, p. 166). 
Ao incluir na narrativa registros de diários ou relatos precedidos pelas categorias espaciais e temporais, indicando dia e local, na tentativa de conferir veracidade ao discurso narrativo, o romance, desde o seu início, busca uma legitimação. Mesmo dando destaque ao triângulo amoroso vivido por Micaela em pleno campo de batalha, tenta conferir um estatuto de veracidade, principalmente ao apresentar textos em forma de artigo jornalístico, bilhetes e documentos que abordam assuntos pertinentes à Guerra do Paraguai que surgem em meio a uma conversa e outra entre a narradora (Coralina) e a interlocutora (Rosália).

\section{Considerações finais}

[...] Há muitas histórias que poderiam passar por romance, e muitos romances que poderiam passar por histórias (WHITE, 2001, p. 137)

As marcas da memória em Cunhataí podem ser perceptíveis nos apontamentos de relações intertextuais que a obra mantém com outras obras já estabelecidas no universo literário, e que revelam a riqueza do romance. 0 maior dos vestígios talvez esteja no resgate da cultura sul-matogrossense e, mais especificamente, na referência que a obra faz ao histórico acontecimento que eclodiu em guerra entre brasileiros e paraguaios.

A partir de narrativas tradicionais, principalmente a registrada por Visconde de Taunay em A Retirada da Laguna, Cunhataí reapresenta os mesmos relatos, mas contados de modo fictício e recriando episódios tidos como históricos. Exemplo: Coralina narra para transmitir experiências à Rosália e para trazer o século XIX (distante em tempo e espaço) para o presente (para o "aqui e agora"), narra para matar a curiosidade, mas também para aconselhar e convencer a amiga Rosália da importância de suas terras, imbuídas de referência histórica. Com tal habilidade, acaba por cativar não só sua ouvinte fictícia, mas os leitores que com ela caminham do início ao fim do romance.
As consequências dessa guerra resultaram não apenas nas demarcações dos limites geográficos do território, mas interferiram social, histórica e culturalmente no próprio constructo identitário daquele que viria a se tornar o povo sul mato-grossense. E é este o lugar a partir de onde se fala em Cunhataí, ambiente fronteiriço, permeado por uma cultura híbrida apresentada pela rica diversidade, seja pelo convívio das duas nacionalidades, brasileira e paraguaia, que partilham espaços, experiências e vidas; seja por vidas atravessadas pelas fronteiras físicas de um espaço territorial, pelas fronteiras da cultura, do saber ou da própria existência, cultura de fronteiras constituídas pela configuração de um espaço compartilhado.

Ao contar a história de vida da Micaela, Coralina, em meio a sua liberdade de lembrar e criar lembranças, acaba revelando, ao final da narrativa, que suas próprias memórias estão entrelaçadas à vida de quem narrara até o momento, já que se declara "[...] bisneta da Micaela e do Capitão Santa Cruz" (LEPECKI, 2003, p. 403), e conhecedora de todas as informações comunicadas à Rosália por meio do diário escrito pela bisavó Micaela. Além de ser portadora do diário da bisavó, ainda relaciona pertences, tais como a carta direcionada à Micaela, escrita pela personagem Ângelo Zavirría de Alencar, e entregue à amada através de Maria Carmem Zavirría, ascendente de Ângelo.

É possível dizer que Lepecki é, enquanto escritora contemporânea, alguém que conseguiu, assim como suas protagonistas Coralina e Micaela, retratar a guerra do Paraguai de uma forma que outros não haviam enxergado até então: um passado ressignificado pelas lembranças, ou pela “[...] memória que postula uma zona intermediária, um equilíbrio instável entre passado, presente e futuro" (ACHUGAR, 2006, p. 222). Cunhataí reflete o debate contemporâneo sobre as fronteiras entre a literatura e a história e permite, com a contribuição da memória e da ficção, que parte da história seja revisitada pela ótica de uma figura feminina que traz à baila o fato histórico, mas por um viés literário. 
Ao mesclar vozes, tanto de personagens históricas quanto de fictícias, a autora apresenta um universo narrativo que emerge da convivência do real e do fictício, revelando, ao mesmo tempo, um mundo ficcional com características próprias do romance moderno, e, sem ter compromisso com a veracidade dos fatos, revela, também, grande poder de verossimilhança e efabulação, que auxiliam a legitimação e a autenticação da obra.

Cunhataí, portanto, é um texto de ficção que tem elementos históricos recuperados pela memória. Ao recriar, à sua maneira, o episódio da Guerra do Paraguai, Lepecki dá voz a personagens históricos e ficcionais e molda o material de que dispõe de acordo com seus instrumentos ideológicos, fornecendo-nos uma ficção. Nessa, agrega diversas áreas do saber humano e traz o significado da Guerra e seus sujeitos históricos, estabelecendo uma rede de relações e interpretações.

O contexto da Guerra do Paraguai, presente em Cunhataí, permite que a obra se entrelace com o horizonte histórico que lhe é subjacente e deixe pegadas (de e em outros textos) e, consequentemente, estabelece um emaranhado, uma rede de afiliações, oferecendo-se como uma obra portadora de um eixo de inumeráveis relações.

Construindo sua narrativa a partir de um fato real, de forma a não se ater a um único relato da história, pressupõe-se que a autora de Cunhataí, ao beber em fontes anteriores, servindo-se, explicitamente, de obras de Taunay e de outros, reinterpreta a história da guerra, reapresentando-a em um novo contexto, no qual, acrescenta a sua interpretação a outras já existentes.

Com isso, a autora de Cunhataí pluraliza a "verdade da história" e, ao mesmo tempo, fortalece a base de que tanto a história quanto a literatura devem ser vistas enquanto constructos discursivos que, a partir da linguagem e por intermédio da memória, permitem que o passado seja revisitado, reescrito, recriado e reapresentado como ficção, evidenciando uma ampla correlação entre as instâncias do saber.

\section{Referências}

ACHUGAR, Hugo. Planetas sem boca: escritos efêmeros sobre arte, cultura e literatura. Belo Horizonte: Ed. UFMG, 2006.

BENJAMIN, Walter. O narrador - considerações sobre a obra de Nikolai Leskov. In: Magia e técnica, arte e política. São Paulo: Brasiliense, 1985 p. 197-221.

CHIAVENATO, Júlio José. Genocídio americano: a guerra do Paraguai. 24. ed. São Paulo: Brasiliense, 1990

DORATIOTO, Francisco Fernando Monteoliva. Maldita guerra: nova história da Guerra do Paraguai. São Paulo: Companhia das Letras, 2002.

FUNDAÇÃO NACIONAL DO LIVRO INFANTIL E JUVENIL (FNLJI). Notícias, v. 26, n. 10, p. 3, out. 2004, Disponível em: <http://www.fnlij.org.br/site/jornal-noticias/item/706outubro-de-2004.html>. Acesso em: 18 jul. 2016.

GUIMARÃES, Acyr Vaz. Seiscentas léguas a pé (a campanha do Apa). Campo Grande: Tribunal de Justiça de Mato Grosso do Sul, 1999.

LEPECKI, Maria Filomena Bouissou. Cunhataí: um romance da Guerra do Paraguai. São Paulo: Talento, 2003.

Entrevista ao Jornalista Alexandros Papadopoulos Evremidis. Cunhataí - Um romance da Guerra do Paraguai. São Paulo: Talento, 2003. Disponível em: <http://www. rioartecultura.com/mariafilomena.htm>. Acesso em: 2 jan. 2016.

SALLES, Ricardo. Guerra do Paraguai: escravidão e cidadania na formação do exército. Rio de Janeiro: Paz e Terra, 1990.

TAUNAY, Alfredo d'Escragnolle (Visconde de). A Retirada da Laguna: episódio da Guerra do Paraguai. São Paulo: Martin Claret, 2003.

_. Memórias. São Paulo: Iluminuras, 2004.

WHITE, Hayden. Trópicos do discurso: ensaios sobre a crítica da cultura. Tradução Alípio Correia de Franca Neto. São Paulo: Ed. Edusp, 2001.

Recebido em 26/07/2016

Aceito em 14/12/2016. 